\title{
Farm Crime Victimisation in Kenya: \\ A Routine Activity Approach
}

Emmanuel K. Bunei

Lecturer, Department of Sociology and Psychology,

Moi University,

P.O. Box 3900

Eldoret, Kenya

Francis O. Barasa

Senior Lecturer, Department of Sociology and Psychology,

Moi University

P.O. Box 3900

Eldoret, Kenya

Contact Author: E. K.Bunei; ebunei2001@yahoo.com, + 254724917456

\begin{abstract}
Farmers globally and Kenyan farmers in particular are facing a number of challenges stemming from continuous change in the social-cultural, economic, and ecological context of farming and a concomitant rise in crimes against farms. While research has been carried out on the theft of cattle and crops, much of it has concentrated on the nature, cause and extent of farm crime, crime prevention, and reporting behaviours, and comparatively little has focussed on applying criminological theory to the situation in Kenya or any other region of the world. Thus, this paper uses Routine Activity Theory to explain what makes certain farms, farmers, and farm property more likely to be victimised. In general, we find support for the basic tenets of the theory as a way to contextualise our understanding of farm crime in the various agricultural regions of Kenya, and suggest that it can be employed for framing farm crime within the diverse geographies and societies of the world today. Indeed, the rapidly changing social-economic environment of agriculture has generated an increase in opportunistic offenders, and the shattering of traditional natural and informal controls that prevented most farm crimes in the past. Both changes create increased visibility and accessibility to valuable and high demand farm properties.
\end{abstract}

\section{Keywords: farm crime, farm victimisation, routine activity theory, motivated offender, attractive target, capable guardianship}




\section{Introduction}

Globally and in Kenya, farm crime has been recognised as one of the significant challenges facing food producers today (Barclay 2001; Bunei 2014; Bunei, Rono and Auya 2016; Bunei, Rono and Chessa 2013; Cheserek, et al, 2012; Gichamo 2011; Jones 2010; Verma 2001). While there is a growing corpus of literature describing the extent and nature of farm crimes around the world, little has been devoted to applying and examining the utility of criminological theory to understanding the economic, cultural and social contexts in which farm crime occurs. Like many other rural crimes, we can study farm crime by examining the way of life and routine activities of farmers to understand the motivation and reasons for their victimisation and how criminals identify opportunities to steal farm property and various agricultural products and livestock. As such, the purpose of this paper is to examine how farm crime occurs in Kenya with the aid of Routine Activity Theory.

There is evidence to suggest that farm crimes in Kenya are increasing due to changing social, cultural and economic conditions that can be understood within the framework of routine activities theory (Anderson 1989; Bunei 2014; Foeken and Mwangi 2000; Gitu 2012; Ochieng, Owuor and Bebe 2013). Earlier studies attributed the occurrence of farm crime to, amongst other factors, cultural practices, unemployment, and poverty that motivate some individuals to steal in order to either get food or to fulfil certain cultural traditions (Anderson 1986). However, more recently, researchers have linked farm victimisation to more commercial motivations, that is, the illegal acquisition of farm property that is later converted or liquidated to cash by offenders.

Though some studies have focused on factors causing farm crimes, less been has done to examine why certain farmers and farm properties are victimised on a regular basis. In fact, to date, there have been few serious studies that have examined the phenomenon of farm crime victimisation utilising place-based theories of any kind (Mears, Scott and Bhati 2007; Osborn 2015).

In this paper, we discuss the three pillars of Routine Activity Theory with a view toward understanding how crime incidents occur on farms and farmsteads. In particular, we critically analyse the sources of motivations that encourage individuals to steal farm property and produce. We also look at the characteristics that make farmers and farm property more attractive to thieves and vandals. Finally, we critically analyse issues related to weak guardianship on farms that create opportunities for theft, and how criminals take advantage in response to the changing routines of farmers and farming. In fact, it is the understanding of how predictable daily routines and farming activities are that in turn lead to farm crime victimisations in Kenya that forms the thrust of this article. It is hoped that this article helps in unearthing and understanding the phenomena of farm crime and addressing agricultural victimisation from an informed point of view, as well contributing to the growing body of literature about of rural crime in general. 
This article consists of four sections. The first section of the paper describes the context of the study by defining the problem and purpose. In the second section, a review of literature on farm crime is provided, taking cognizance of the characteristics of farmers, farms and farming, as well providing an overview of Routine Activity Theory. Thereafter, a presentation on the three tenets of the theory is provided, using the available literature about farm crime in Kenya. The last section offers concluding observations and thoughts.

\section{Literature Review}

\section{Nature and characteristics of farming, farmers and farm crime in Kenya}

In order to understand farm crime victimisation, it is necessary first to understand the characteristics of farmers and farms. Indeed, agriculture remains the main engine of Kenya's economy, despite 80 percent of the land being too dry to yield meaningful livestock and crop production (Republic of Kenya 2010a). Kenya's agriculture is mainly rain-fed and is almost entirely dependent each year on the two rainy seasons - the long rains from March to July, and short rain season from October to December. A large proportion of the country, approximately 80 percent, is semi-arid and arid with an annual rainfall average of 400 millimeters or slightly less than 16 inches of precipitation (Republic of Kenya 2010a). It is further characterised by the dominance of primary production, with little or no on-farm or off-farm processing of crops or other produce. A sizeable amount of what is produced on Kenyan farms is consumed by the farm family or sold at a marketplace located in an urban centre (i.e., subsistence agriculture) (African Agriculture Review 2012).

Farmers tend to have certain daily routine activities, starting off with house chores, then moving on to farm-related work until the late afternoon, returning back home at early evening and sleeping as early as 1900 hours (7 PM). The weekly routine also forms a certain pattern, with Mondays through Fridays dedicated to farm work or off-farm employment, and weekends devoted to worship and religious observances. This pattern is very predictable and is one that many motivated criminals can identify and then target with precision suitable farm property based on the routine activities of these food producers.

Further, most farming is carried out on farms averaging only $0.2-3$ hectares $(1$ hectare $=$ 2.47 acres) that are rented, leased or owned. More than 75 percent of agriculturalists farm for both subsistence and commercial purposes. For some farms, land used for cultivation or grazing of farm animals is located far from the homesteads of the farmer, often more than a kilometre. Further, farms are generally left wide open with minimal preventive measures, such as barbedwire fencing (Bunei 2014). Almost all farmers rely on casual inspection to monitor their properties, and this affords only minimal guardianship. Dogs are common on farms, both for 
general security purposes as well for pets around the homestead. However, most dogs are not sufficiently trained to offer effective guardianship. Farm structures are mostly constructed with frail and weak materials such that it is relatively easy for someone to break into them. Most farm machinery is not housed and mostly remains unguarded during the night and in off seasons. During peak times, such as planting and harvesting seasons, most farmers hire part-time employees and sub-contractors, some of whom take things while on the job or return later to steal property from a farm now familiar to the offender.

A majority of Kenyan farmers are smallholders and fairly unorganised. This small-scale production accounts for 75 percent of the total agricultural output and 70 percent of marketed agricultural produce. Most farmers in Kenya are growing old, with the majority between 50 and 80 years of age (Bunei 2014). As well, farming is not attractive to many young people in Kenya (Indakwa 2013). To many, a farmer is someone like their parents and grandparents, performing dirty, backbreaking labour in the fields, and with little economic benefit. Lastly, Kenyan farmers rarely insure their farm property, including expensive machinery, against theft or loss from natural causes (Stavrou 20002).

For a long time, the agricultural sector in Kenya was the least affected by crime, but in the last decade, farm crimes have risen beyond acceptable levels (CARE 2010; Bunei 2014; Gitu 2012; Juma, Mawusi 2004; Nyangena and Yesuf 2009; Kilalo, Olubayo, Obukosia and Shibaino 2009). The most prevalent farm crime that occurs in Kenya is a property crime, which includes the theft of livestock, produce, machinery, equipment and supplies. According to Bunei (2014), nine in ten farmers have experienced a crime within a span of five years. Furthermore, more than ten counties of Kenya have borne the brunt of criminal activity. These counties are mostly in the wetter, western half of Kenya (see Figure 1) and include Uasin Gishu, Narok, Trans Nzoia, Nakuru, Nyandaurua, Elgeyo Marakwet, Nyeri, Kiambu, Muranga, Taita Taveta, among others (Bunei et al 2013). For example, coffee theft is proving to be a headache to struggling coffee farmers in Nyeri County, while green maize thieves are descending to the green fields of Trans Nzoia County (East Africa 2011 and Gitu 2011). Like other counties, theft of wheat at night in Uasin Gishu is so rampant that farmers are no longer bothered by it, that is, it is expected that some percentage of their crop will be lost by thievery (Bunei 2014). At Taita Taveta, banana thieves are striking in broad daylight to take advantage of ready markets at towns in the coastal areas of Kenya (The Standard 2014a). In Nyandarua County, potato thieves are giving farmers sleepless nights as they are now required to guard their produce from being stolen. 
Farm Crime Victimisation in Kenya: A Routine Activity Approach - Bunei and Barasa

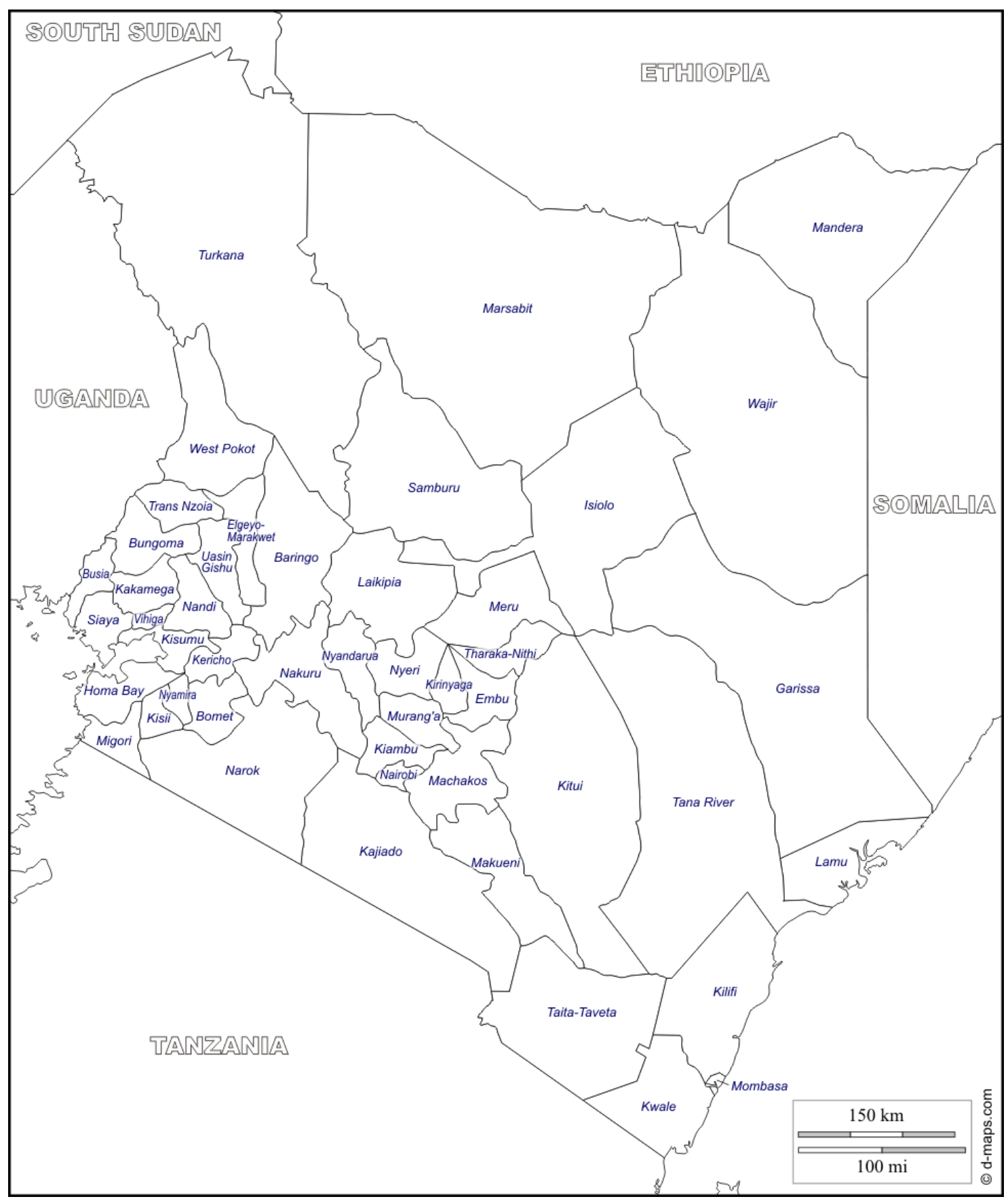

Figure 1: Counties in Kenya 


\section{Routine Activity Theory}

Routine Activity Theory is one of the best-known place-based theories in criminology. It views crime as a direct product of daily lifestyle activities by both potential victims and potential offenders. It was first proposed as a macroscopic theory (Cohen and Felson 1979), but later revised to fit micro level situations in order to explain how victimisation or offending occurs at particular places, to certain kinds of targets, and among specific groups or types of people. For Felson (1998), crime is a product of everyday social life that characterises a specific person or community. The theory is anchored on the presupposition of human frailty or vulnerability, and the role of temptation (i.e., motivation), and provocation (i.e., perceived opportunity) in facilitating the occurrence of crime (Maguire, Morgan and Reiner 2007). According to Cohen and Felson (1979), crimes occur when motivated offenders meet suitable targets in the absence of capable guardians. However, they stress that there are many motivated offenders in society and only when opportunity presents itself in terms of an increase in the attractiveness or number of suitable targets and/or a decrease in capable guardianship does the volume of crime increase (Burke 2009; Maguire et al 2007).

A motivated offender is anyone who has the tendency or inclination to commit a crime (Cohen \& Felson1979). A target refers to the characteristics of an object or person to be victimised. A target can be person, place or property. The choice of target depends on four factors: (1) value; (2) transportability or inertia; (3) visibility; and (4) accessibility. These four factors determine target attractiveness and offenders' decisions on whether to commit a crime. For example, an increase in any of these qualities increases the likelihood of victimisation (Cohen and Felson 1979). Value may entail the economic, social and cultural aspects of the property or person against whom a crime is committed. Different types of offenders possess varying and subjective values about different targets, depending on their analysis of the situation (Cohen and Felson 1979 and Maguire et al 2007). For example, thieves go for properties that are easily converted to cash, have high and ready market value, are small in size, weigh less, and easily transported. Another major ingredient of suitable target is degree of visibility. This entails the ability of perpetrators to clearly identify the property and have a sense of certainty that it can be stolen without getting caught. The last ingredient is accessibility, which is the ability to reach the target in the shortest time and space and escape or retreat fast. In the same vein, Felson (2002) observes that properties which are concealable, removable, available, valuable, enjoyable and disposable are more likely to be stolen when the opportunity arises.

The last dimension, according Routine Activity Theory, is the absence of a capable guardian. As Felson (1979) defines it, a guardian is someone or something capable of preventing a crime. Bursik and Grasmick (1993) noted that guardianship is the availability of others who may prevent crimes by their mere presence or that remind a motivated offender that someone may be watching (Cohen \& Felson1979). As such, it is not limited to the police, security guards 
or owners, but also neighbours, friends, relatives, passers-by or physical measures such as locks, alarms, and Close Circuit Television (CCTV). All of these can function as substantial obstacles to offenders (Clarke \& Felson, 1993). For instance, the availability of people or passersby in an area increases levels of natural surveillance, which can in turn increase offenders' perceptions of the greater chance of detection and apprehension should they commit a crime, thereby discouraging offending behaviour. Having reviewed the literature on farm crimes in Kenya and discussed the theory of routine activity, we now turn to methods of study.

\section{Methods}

The primary methodology used is qualitative in approach, but predicated on both primary and secondary sources. This was done through a desk study and survey of one selected county in Kenya. Supplementary information to strengthen the findings was gathered from media reports, court judgments, and selected key respondents from the county. We also used observation to support data generated from secondary sources. We began by compiling literature about farming in Kenya before embarking on a search for data from journals, theses, media (newspaper and television) and court cases. Our point of focus was incidents of farm crimes that have been documented in Kenya. We were particularly concerned with the nature and characteristics of perpetrators of farm crimes, what motivates them to victimise farms, what types of targets they victimised, and the possible presence of existing farm crime prevention measures. The major approach of the analysis was thematic in intent. Hence, we identified themes or patterns, as per the basic tenets of Routine Activity Theory.

\section{Results}

In this section, we examine farm crime based on the three ingredients that form Routine Activity Theory, using materials collected from different sources in Kenya. We align each and every incident of farm crime so as to answer the research question mentioned earlier. In particular, we are looking for the reason that leads to certain farms and farmers being victims of farm crimes against the three elements of the theory.

\section{Presence of motivated offenders}

In farming communities, an offender is someone who has criminal inclinations to steal or vandalise farm property or produce, regardless of the motive. Hence, in this article, we operationalise motivated offenders as individuals who have a tendency to steal irrespective of target and opportunity. Though Routine Activity Theory does not expressly explain who the motivated offender is, it does assume that a tendency to offend is a given. Hence, our focus was on sources of motivations that create or make individuals more likely to perpetrate a crime against farms. We operationalised offenders in terms of farm workers and family members, the 
poor, the under-employed and unemployed youth, organized thieves representing rural-urban links, and extension workers and farm consultants. We emphasize that these are not mutually exclusive categories of motivated offenders, but instead, conditions within which individuals may be motivated to target farm property and farm animals for theft.

Farm workers and family members: From literature reviewed in Kenya, it was observed most offenders live either near or within the vicinity of farm property (Bunei 2014; Gitu 2011; The Standard 2011). One such category of offenders is the farm worker. In both rural and periurban Kenya, most farm labourers are poorly paid (often less than a dollar a day) and they often are compensated through provision of food in terms of milk and vegetables and in many cases, monetary payment may be delayed for several months (Bunei et al 2013). These wages are far below what is required to take care of the basic needs of workers and their families. Farm workers may feel cheated and exploited after working hard to increase the profits, wealth and prosperity of their employers, as well as guarding expensive farm property they themselves do not own. These conditions predispose some to opt to pay themselves what they think their labour is worth by stealing farm property or offsetting debts. As well, this form of theft may serve as a form of discipline to the farmer, that is, of making the farmers aware that they should treat their employees more fairly (Bunei et al 2013).

It is common to find Kenyan farmers hiring seasonal workers when farm work activities increase, especially during busy planting, weeding and harvesting seasons. Most of these seasonal workers are itinerant workers, often travelling in groups, who are under pressure to provide food for their family and to pay rent (Bunei 2014). This creates a compelling motivation to steal farm produce, especially cereals and fresh produce. Some thieves conceal themselves as workers so they can scout out, identify and then steal farm produce and property at a later, more opportune time. Others may even steal while working on the farm or farm premises. In some cases, disgruntled ex-farm workers steal farm produce or pass on information for money about points of entry and storage of the property to prospective offenders.

Especially among workers, but also family members and relatives, motivations to steal farm property is based on the desire to get money to buy more than basic commodities. Francis and Nyamongo (2005) and Bunei (2014) found that petty theft of farm produce, especially coffee, chicken, and grains, are linked to the need of young men to feed their alcohol and substance abuse habits. They steal to buy things that meet their pleasures, especially alcohol, cigarette and other drugs (Bunei 2014 and Indakwa 2013). The urge to consume alcohol or use a certain drug, especially chang'aa (a traditional, home-brewed spirit made from millet, corn, or sorghum) compels addicts to do everything possible to get a drink, even if it involves stealing farm property, especially grains which are easily sold to local brewers. Some desperate alcoholic employees, neighbours, family members and relatives often exchange valuable farm items and produce for alcohol (Indakwa 2013). 
Some farmers in Kenya, especially men, utilise free family labour in terms of children and spouse to weed, plant and harvest. When it comes to selling and cashing in on what is produced, they may be the sole beneficiaries, and sometimes display a complete disregard for the people who helped them (Bunei 2014; Bunei et al 2013). In most cases, these farmers rationalise their actions by arguing that they are providing basic needs and education on behalf of these dependents. The rest of the money belongs to them and for their pleasures. However, in recent times, there have been many changes in the perceived needs of family members, and these go beyond the provision of basic needs. Youths and adolescents want money to not only access a phone, but to acquire a "trendy" phone; and not only to have proper clothing, but new "fashionable" clothes. It is the gap between what parents can provide and the newly formed desires of disgruntled children, especially boys, that motivates them to "help" themselves by stealing farm property. As well, some jealous relatives and dissatisfied employees steal farm property or facilitate crime on the farms by collaborating with thieves or selling information to them, in exchange for money.

The poor, the under-employed and the unemployed: Food insecurity due to poor wages, poverty, and both under-employment and chronic unemployment can be a strong motivation to steal from farms (Francis and Nyamongo 2005; The Standard 2014b; Verma 2001). Sevelius (2012) observed that theft of farm produce is one of the behaviours associated with the rural poor in Kenya. In Kenya, crop theft has been called a crime of "need” as people, especially hungry farm labourers, relatives and neighbours without sufficient access to food, steal from farms out of desperation (Bunei et al forthcoming 2016; Francis \& Nyamongo 2005 and Verma 2001). Root crops and green maize theft in particular is rampant, which is seasonal in nature and mostly occurs in cereal growing counties in Kenya, especially Trans Nzoia, Uasin Gishu and Nakuru Counties (Bunei 2014). As Verma (2001, p 187) noted:

"Another result of economic poverty is that escalating prices and increased financial obligations have increased food scarcity and hunger. This, in turn, has increased instances of crop theft from people's land".

In addition, the number of poor farmers and farm workers is increasing, and along with the increased costs of basic necessities caused by inflation, extremely poor families and those with a large number of dependents are frequently compelled by circumstances to cheat or even steal (Bunei et al 2013). Thus, it is common in Kenya to find employees stealing a few eggs, milk and fresh farm produce to feed their families (Bunei 2014). As inflation creates greater financial stress, more people, especially drug addicts, unemployed individuals and low paid workers find it attractive to steal rural "gold" - such as cockerels or roosters, bulls, and injector pumps, among others - which are easily re-sold. Also, theft of farm produce in Kenya increases when workers have depleted their stocks between April and September of each year (Bunei 2014). 
Furthermore, as the cost of farm inputs, such as fertilizers for planting and top dressing, seeds, chemicals and fuel increases, the theft of these items escalates. Similarly, herbicides and pesticides are expensive and are sold in larger amounts, often out of reach to most smallholder farmers. Perpetrators, especially farm workers and relatives, steal these inputs and sell them at cheaper prices for cash, such as to other unscrupulous farmers (The Standard 2011). For example, farm inputs especially fertilizers, are sold in large quantities, usually in 50 kilogram (about 110 pounds) increments and at a price higher for smaller scale farmers, who require limited quantities (usually of less than 10 kilograms or about 22 pounds) to use on smaller plots (less than 0.1 acres). Hence, small landholders find it attractive to buy a precise amount of stolen fertilizer at a cheaper price than more fertilizer than they need, but at a lower per unit price (Bunei 2014).

Another source for the motivation of farm crime offenders is unemployment, especially among youth (Daily Nation 2013; Indakwa 2013). As at 2014, 46 percent of Kenyans were unemployed, with the majority being youth. Even though in rural areas an individual may find temporary employment, the amount earned is far too low to meet the cost of increasingly modern lifestyles. Indeed, most farmers readily blame youth unemployment for thefts on farm (Bunei et al, forthcoming 2016). Further, the aspirations and needs of younger people (fashion, entertainment and electronic gadgets) are continuously changing. With limited options for coping with unemployment, poverty, and few opportunities to earn money, many young people resort to engaging in activities such as gambling, using drugs, playing pool, and watching movies, among others. All of these pursuits requires cash (Daily Nation 2013). Unfortunately, young men who could be working on a farm congregate around market centres playing ajua ${ }^{1}$ and drinking $b u s a a^{2}$ (Indakwa 2013) They dislike farming because they view it as a dirty, rural activity that is for older people. They prefer to watch oversees televised football, to gamble, to tout (i.e., aggressively selling) at bus stops, and to steal chicken, goats, fuel and other farm properties to sustain their lifestyle.

The idleness of youth has been used by some unscrupulous business owners, especially street and roadside vendors, who enlist their services to provide information on the number of cattle at farmsteads, types of animal shelters, possible homes to raid, and possible escape routes, all in return for a small fee (Daily Nation 2013). Forces of demand and supply create motivations to reap huge profits by merchants who want cash from the high disposability of stolen farm produce (Business Daily 2011; Gitu 2012). Unlike other commercial products, farm produce is frequently in short supply, creating a rise in demand and opportunities to make a good profit. The result is people steal farm produce based on supply and demand factors, especially green maize, coffee, livestock and bananas (Bunei 2014). Young offenders will take advantage to target farms that are less guarded, but highly lucrative to steal from in order to supply a ready market in a nearby town. As Omiti (2006) observed, increased farm thefts in Kenya is associated with 
greater market integration than in the past. Furthermore, demand for some farm produce increases with the onset of certain seasons, such as ripening time and during Christmas and other festive occasions (Bunei 2014). It is during these time that unscrupulous business people enlist the services of unemployed youth to find for them bulls, cockerels and other animals to cash in during periods of high demand for meat products from people living in cities (Daily Nation 2013). Gitu (2012) also observed that favourable international coffee prices have heightened coffee berry and parchment theft in Central Kenya, which is consistent with Routine Activity Theory and demonstrates the link between global market forces and the context in which local expressions of farm crime can be understood.

Organized thieves and rural-urban links: There are many enticements for individuals to steal farm property and produce for re-sale to the many hotels, restaurants and pubs located in Kenya's major cities (All Africa 2010; Gitu 2012; Kaprom 2013). There is also a number of businesses dealing with value-added agricultural products associated with transportation, juicing, roasting and so on, that provide both motivation and opportunity for businesses to increase their supplies or profit through the purchase of stolen farm products or by "skimming off the top." Urban centres provide the critical mass of population who are looking for fresh and organicallygrown farm produce which motivates criminals from these urban areas to go out and steal from farms (Bunei et al 2016). For Gitu (2012), hawking of farm produce, especially coffee and green maize, increases farm theft because thieves collude with brokers and business people to fleece farmers from less guarded produce. There is also a continuous demand for red meat in the major towns of Kenya - namely Nairobi, Nakuru, Mombasa - that also is contributing to a discernible rise in cattle rustling in the northwestern part of Kenya (Kaprom 2013; Kenya Human Rights Commission [KHRC] 2010; Osamba 2000). Thus, with the forces of demand and the opportunity to cash in, business people find it attractive to source from unscrupulous brokers who acquire stolen farm produce to sell on the black market (Gitu 2012). For business people, farm produce is just another input cost that needs to be reduced and they can save money and make more profit through buying from any person who offers the best price or product that can be delivered immediately (Makiche 2013). In the past, most criminals stole farm property or produce before finding a buyer, but currently, it is just as likely that criminals are requested by business people to find for them certain farm products (Bunei et al 2013). This is a type of customised stealing.

Moreover, with the proliferation of motorcycles in Kenya, commonly known as bodaboda ${ }^{3}$ in Kenya, farm thefts have increased in equal measure. This kind of vehicle gives criminals the capability to travel to remote areas, and steal farm property, and then quickly retreat back to the city. For instance, in Taita Taveta County, farmers blame bodaboda operators for an escalation of banana theft (The Standard 2014a). In Nyandarua County, a suspect was found with two stolen sheep, trying to escape with them by motorcycle. One reason why criminals prefer a motorcycle is that they offer rapid flight, greater mobility, and they blend in, hence, it is a discreet or anonymous form of transportation that has an indistinguishable appearance. For 
instance, many rural residents are not able to identify if a particular motorcycle belongs to someone in the community, a passer-by, or a thief. Indeed, modernisation of transport systems, infrastructure, and machinery not only improves the lives of farmers, but also opens up and creates a motivation for criminals to steal farm property and make a successful escape before the property is discovered as missing.

Agricultural professionals: Finally, hitherto unacknowledged and unheard of until recently, there are now individuals who possess professional knowledge or expertise about farming but who are now engaging in the racket of fleecing farmers (The Standard 2014c). Many farmers have been defrauded hundreds of thousands of shillings by criminals who sell them inappropriate farm inputs, seeds and farm implements. Some criminals masquerade as professionals in certain fields of agriculture and bilk a great deal of money by offering fake services to farmers. Their motivation stems from an increasing urge amongst farmers who want to adopt modern technology, seeds and methods of farming. Further, most farmers trust individuals who work with a university because they believe that they are experts with integrity. Indeed, motivated con-men and rogue consultants and extension workers have found a niche in advising about farming practices to dupe unsuspecting farmers because some farmers are not exposed to new technologies, pesticides or herbicides and they mostly or entirely rely on experts' advice (Bunei 2014). Hence, these criminals capitalise on this opportunity, even while engaged simultaneously in legitimate extension work. Some criminals have masqueraded as Artificial Inseminators only to use or sell fake animal semen. A celebrated case in Kenya is one that happened in Kakemega county where farmers were duped into surrendering their cash to a man who posed as a lecturer from a local educational institution and claimed to be a professional in animal production. This individual promised farmers to deliver high-quality heifers, only to vanish after stealing from them through down payments (The Standard 2014c).

Having discussed the sources of motivations of farm thieves and the varieties of individuals who may steal from agricultural operations, we now turn to a discussion of features and characteristics that make certain farmers, farms and farm properties attractive to motivated offenders.

\section{Presences of suitable targets}

In this section, we discuss characteristics of various farm targets. We operationalised suitable targets in terms of: (1) demographic characteristics of farmers; (2) type of farm produce or livestock; (3) location or place where a theft occurs; and (4) proximity to urban centres. A review of literature from journals, court cases and other media reports indicate that motivated offenders have an inclination towards victimising certain kinds of farmers, the time when a crime occurs on an agricultural operation, and the types of property targeted. Indeed, certain farmers 
are more likely to lose property through theft. In the same vein, certain farm properties are more likely to be stolen because of their value, accessibility, disposability and removability.

Characteristics of the farmer: One major characteristic related to the suitability of the target is associated with the characteristics of the farmer, especially in terms of sex and age (Makiche 2013; Bunei 2014). For example, cattle theft in Kenya is significantly related to the sex of the farmer because criminals often target homesteads that are perceived to have weak (both psychologically and physically) male members, female headed households, and households without male members. Responding and directly confronting thieves requires courage, and farmers without adequate physical and psychological characteristics suited for confrontations may more likely be the victims of crime. Specifically, their reputation may have already been "scouted out", that is, criminals who target these farm operations have a greater sense that they will not be confronted directly. This is also a characteristic of capable guardianship, but is mentioned here because it is likewise a characteristic of the target.

Age is one factor related to this perception, as with physical decline comes a lessened ability to defend oneself or one's property. As well, dishonest children and employees are notorious in defrauding aging farmers by persuading them to sign vital documents, such as cheque books, over or under-weighing farm produce that can be taken for sale to a market or as reimbursement for work, miscounting money, or selling farm property illegally or without permission. Research shows that cattle raiders in Migori and Kisii counties of Kenya target farms that have elderly couples who are less able to become aware of intruders, or farms with many elderly neighbours who have a lessened ability to alert their farm neighbours. Further, older farmers tend to go to sleep earlier in the evening, giving thieves' more time to execute their plans, especially in the early morning. As Makiche (2013, p 3) observed:

"....the attacks along the border are coordinated often targeting homesteads of widows, elderly couples, polygamous families and bereaved families. Others targeted are those with perceived 'weak male members and families who are out on a journey."

Type of farm produce or item: In Kenya, a majority of farmers engage in mixed farming and it is rare to find farmers engaged exclusively in only crop or livestock farming. From newspapers stories, other research and documents based on court judgments, the general pattern is that thieves tend to target farm property rather than a specific type of farm (Bunei 2014; The Standard 2014c). As such thieves are interested in farm products that are in high demand, easily sold or readily consumed. Indeed, livestock - especially cattle, goats and poultry - are frequent targets of criminals because livestock products are in high demand and therefore highly lucrative for thieves. In fact, thieves tend to steal cockerels, bulls and rams as compared to female livestock, as the meat from these animals is considered sweeter by most consumers (Ochieng et 
al 2013). Further thieves are more likely to steal mature stocks and poultries than younger ones since the mature ones fetch greater value and are in greater demand as food.

Like livestock, farmers who grow crops that are in high demand for food or can be easily sold at the market, are more likely victimised in countries like Kenya. These include maize, coffee, fruits and vegetables. Further, farm items such as injection pumps and chemicals are targeted by criminals because of their price and demand for these items. As Stavrou (2002) observed, tool and equipment theft is the most prevalent property crime on Kenyan farms, with over 84 percent of farmers having experienced this crime. Chemicals that are of high value are mostly stolen and mostly occur on farms when chemicals are being used for cultivation (Bunei et al 2013; The Standard 2015a). Offenders quickly pour chemicals into small containers and either sell them on the spot if buyers are around, or hide the chemical to be sold later. Further, some farm produce, such as peas, sweet potatoes, sugar cane and fruits, which are consumed fresh or green, are more likely to be stolen than those that need further processing or cooking. In Taita Taveta County, banana theft is a persistent problem which has been fuelled by an increasing preference for matoke ${ }^{4}$ by most urban consumers (The Standard 2014a).

Place of theft: Stocks or poultry are stolen both at the premises and from grazing fields or places where thieves can operate without being seen, especially at night (Daily Nation 2013). Crops are most likely stolen in the fields. Most farmers with a land size of over 200 acres have experienced at least one type of farm theft in their lifetimes (Bunei 2014). Some farm thefts are frequent and common on large farms, such as the theft of maize, hay, grass and wheat (Foeken and Mwangi 2000; Juma, et al 2009). Further, huge tracts of land are used to commit other forms of farm crime, such butchering of stolen stock and hiding of stolen farm tools, among others. For instance, in Kitui County police unearthed a syndicate where stolen goats were butchered on the premises of a maize plantation and sold to unsuspecting customers. However, this pattern does not hold true for farms near urban centres where thieves indiscriminately target farms without regard for size.

Remote plots of farmland are more prone to theft than areas near the homestead. The longer the distance from the homestead, the more likely guardianship is reduced (Tittonell, Shepherd and Giller 2007; Foeken and Mwangi 2000). Further, there is a theft management challenge faced by farmers who live far from farmlands, providing the perfect excuse for thieves to steal because it is harder for these agriculturalists to keep track of machinery and other farm properties or to notice when fruits, vegetables and other crops are missing (Juma et al 2009). Some crops, such as beans, are more at risk of theft if there is a long distance from the farm premises. However, thefts of coffee berries occur frequently near a millers' store (Gitu 2012). Analysis of court cases shows that most stocks are stolen on the farmer's premises, and often from a building or shelter of some kind, as shown from excerpt below. 
The Appellant Benard Simiyu Juma was charged and convicted of the offence of stealing stock contrary to section 278 of the Penal Code. He was sentenced to serve five (5) years' imprisonment....The facts of the case are that the complainant's cow was tied in the cattle shed in the night of $8^{\text {th }}$ and $9^{\text {th }}$ day of June 2009 at Kewa Village in Bungoma District. The following morning, the complainant PW1 found the cow missing. It was later recovered by police through the help of PW3. (Republic of Kenya 2010b).

Nearness to urban centers and urbanisation: In Kenya, close to 60 percent of farm crime occurs on operations near or within urban centres (Bunei 2014; Foeken, Owour and Waver 2002; The Standard 2014a). Farms near urban centres that are also located off back roads, less travelled public roads, and those not next to residential developments witness more frequent thefts than their counterparts in more remote areas. Studies show that perpetrators of farm thefts have preferences for farms with easy access from a road, as this provides a means for quick escape, often with the use of a vehicles, such as a car, truck or motorcycle (Gitu 2012). For example, public roads tend to offer opportunity for both spontaneous and planned thefts to occur as criminals have the perfect opportunity to strike and retreat into a crowd. Further, farms and farm premises adjacent to highways are more at risk of theft than those far from a major road (Bunei et al 2013; Foeken et al 2002). Bare/stripped maize stalks are mostly seen in farms adjacent to public roads or near a residential development, indicating the extent that visibility and accessibility play in regard to the target for farm crime.

\section{Absence of capable guardians}

The final element of Routine Activity Theory is capable guardianship, which refers to the presence of barriers that can ward off or in some other way prevent thefts from occurring; failure of which can create opportunities for theft. In this paper, we operationalised guardianship in three ways: (1) physical barriers, including locks and dogs as alarm animals; (2) ecological barriers, including both darkness and light; and (3) social barriers, including family unity, farmer-employer relationships, and farmer-community relationships. One way of limiting offending is to increase the guardianship of farms or of specific areas on the farm property or by securing specific types of property, animals or produce. This can be in the form of physical or social structures that limit the chances of thefts since thieves are more likely to be noticed. Since some farm thefts occur at night and in remote places, improving guardianship can greatly reduce the chances of a farm theft occurring. The following is a discussion of barriers that if absent, weak or ineffective, will facilitate farm crime victimisation in Kenya.

Absence or ineffectiveness of physical barriers: Physical barriers refer to guardianship measures that prevent a motivated offender from accessing suitable targets. These barriers include guard dogs, locks, fences, storage facilities, and so on. They provide the first level of 
protection against crime. Unfortunately, in Kenya, especially on more remote farms, physical barriers are nearly non-existent (Bunei 2014 and Gitu 2012). Indeed, securing farms and farm property is financially out of reach for most farmers. A few large-scale farmers can afford to employ guards but regrettably, these same guards can be offenders, stealing the same property they are supposed to defend.

Another tactic that many farmers in Kenya employ is the use of dogs (Bunei et al 2013, 2014). As mentioned previously, almost all farmers rear at least one dog for purposes of alerting farmers when intruders or strangers, including thieves, are present. Though most farmers rear dogs for security purposes, regrettably most of them are not fed well and are not trained to offer effective guardianship. This has created opportunities for criminals to compromise the dogs. For example, in some cases, criminals feed dogs at night with meat to make them friendly and to keep them busy gnawing on bones while they steal farm property. Some criminals will even go so far as to poison dogs. Furthermore, most dogs are not effective because some offenders especially neighbours, friends, employees and relatives, may be known to the dog and they can easily prowl about at night without the dogs barking (Bunei et al 2014).

Many storage facilities, animal shades, and chicken coops in Kenya are constructed with frail materials which cannot offer effective protection (Ochieng et al 2013). Historically, Kenyan farmers keep their harvest in stores commonly known as granaries, which are rarely locked. Worse still, chickens are often left to sleep on trees near the homestead (Ochieng et al 2013). In recent decades, farmers have taken up the practice of housing their poultry at night in structures, but they are not strong and are mostly made from by-products such as carton boxes and off cuts. Constructed shades, where cattle or other animals seek respite from the sun, are mostly located away from the homestead. Like chickens coops, these sheds are constructed from materials far too inadequate to stop thieves, and so far away from the homestead that capable guardianship is reduced. Hence, they offer zero protection.

Even worse, a majority of rural farms and homesteads have numerous entry and exit points. The use of "no trespass signs" is non-existent on most rural farms, and aside from simply marking the boundary of a farm's property line, it is highly problematic if signs alone provide capable guardianship. Though some Kenyan farmers fence their land, it is not for purposes of preventing farm thefts, but for border identification and protection of farm property from disturbances by domesticated animals of both owners and neighbours. This absence of warning signs and the presence of numerous points of entry gives criminals opportunity to access farms and farm property easily, as well providing easy egress or escape.

Branding of tools and equipment is rarely used by farmers in Kenya, giving sufficient opportunity for criminals to claim ownership of stolen livestock and to dispose of them easily. Furthermore, it is nearly impossible to serialise farm produce with identification numbers, 
making it difficult to trace stolen farm property. Small tools are almost never marked with any kind of identification (Bunei 2014). This makes it hard for police to adequately charge suspected offenders since farmers do not have substantial proof of their theft claims. Most farms operate with numerous farming tools and implements and this poses a difficulty for farmers to continuously keep inventory of their tools and therefore difficult to distinguish between theft and loss of tools when they come up missing. For example, during times of farming such as planting, weeding and harvesting seasons, farmers hire employees to help with farm activities, who then steal these properties and convert the purloined items to cash. Storage of some farm machinery, such as combine harvesters, poses another difficulty for farmers, especially during busy times of the year such as harvesting season. Matters become worse for farmers when machines break down and they are unable to tow them to safe places, such as a friend's home or their own home. Sometimes farm machinery is left unattended in the field for many days and nights while farmers seek replacement parts (Bunei et al 2014). This provides a perfect situation for opportunistic offenders to steal parts off the machinery.

Ecological barriers: These refer to environmental and geographical factors that limit or protect farmers from providing capable guardianship to farm property and farms. This includes factors such as the absence of light or presence of darkness and when it's raining (Makiche 2013). Research indicates that most farm thefts in Kenya occur at night, after it rains, when guardianship is limited and visibility is curtailed. Often farmers are asleep, tired and in other ways are not as alert. It is at night that passersby, especially local people, are rare and would notice intruders.

Further, the trend of family members being absent from the home and surrounding farm property has decreased guardianship and makes these places more vulnerable to theft. For example, more women are now engaged in employment (both formal and informal), children are at school, and farmers (fathers) are busy supervising remote farms. Those who work on the farm (both extended family and non-family employees) who are motivated to steal are presented with greater opportunity to steal. Indeed, crop thefts and farmstead burglary tend to occur towards nights and Sundays or Saturdays when homes are deserted for church attendance (The Standard 2011). In Nyeri County, for example, coffee berry thieves are striking at night during weekdays and Sundays when family members have gone to church. Livestock are mostly stolen from homesteads of the farmers at night (often between midnight or 00.00 hours and 4 AM or 4:00 hours) when capable guardianship in terms of owners and locals who may be passing by are absent and roads are less crowded (Bunei 2014; The Standard 2015a). In the same vein, a review of court cases and judgements showed that livestock theft is prevalent during nights as demonstrated by the following example.

"......the owner of the livestock which had been slaughtered, Mary Nyambura, said the suspects broke into her home at around 4.00 am and drove away with the 
animals. A neighbour heard commotion and informed the granny and with help of motor cycle operators, they managed to track the suspects...." (The Standard 2015b).

In Uasin Gishu County, wheat thieves strike at night near the edge of properties of largescale farms when the owners are asleep (Bunei et al 2013). Thieves also tend to steal farm property, especially chickens during the night when it is raining because the ability to hear noises from inside the owner's house or the dwellings of trusted farm workers is impaired (Makiche 2013; Ochieng et al 2013). It is also during rainy times that roads have less traffic and most people are inside their houses rather than outside that thieves find it attractive for stealing vegetables, fruits, and green maize. Moreover, farms situated next to public roads are more frequently victimised as capable guardianship is sufficiently reduced because motivated offenders can easily access these farms and retreat quickly to public places where they can blend in (Bunei 2014). In addition, farm employees who have authority to work on farms, open stores and feed livestock can take advantage of the absence of guardianship measures by owners to steal farm property, especially small items like spanners, eggs, cereals and so on.

Social barriers: Social barriers refer to guardianship measures that dissuade, scare and discourage offenders from taking advantage of situations. This includes factors such as the absence of family members, families that are not cohesive or where there are conflicts amongst family members, poor farmer-employee relationships and poor farmer-community relationships, and weaker values than in the past within Kenyan society about family and community.

One social barrier that has weakened in Kenya is the decreasing importance of family and communal value systems (German, Masuku, Odenya and Geta 2006). Notably, many young people do not appear to hold hard work as an important virtue and are content at doing nothing all day. Some youth are obsessed with self-gratification and look for ways to make money quickly, regardless of the risk. Kenya, like other African countries, is undergoing rapid transformations in its social structures, such as a weakening of clanism and kinship/extended family networks (Indakwa 2013). These weakened networks lead to less guardianship by local people in what used to be tight-knit rural communities. As a result, immediate family members, neighbours, and friends who in the past served as a type of natural guardianship no longer perform this function (Bunei 2014; Bunei et al 2013).

Furthermore, most farmers in Kenya do not take security of their farms seriously (Business Daily 2011; Bunei et al 2016). While some farmers are now increasing their security to some extent, regrettably, a majority lack knowledge and awareness of protecting farm property, hence, creating opportunities for experienced criminals. It has also been noted that some behaviours of farmers contribute to reduction in guardianship on farms (Bunei 2014). For example, care and storage of door keys is not keenly guarded. They are easily stolen or duplicated without 
knowledge of the farmer, especially by unscrupulous family members and farmworkers with access to these storage places. As Bunei (2014) observes, proper treatment of employees leads to proper caring and protection of farm property, and vice versa. For example, it has been observed that some farmers are fond of utilising free family labour without any form of compensation, which tends to lead to feelings of exploitation by children, especially teenagers.

Moreover, some farmers delay payments or pay in small amounts or through barter with farm produce. This tends to generate motivations for revenge by stealing from the farm and lack of care of property of farm owners' property by workers. Indeed, developing and maintaining good relations with employees can be an important type of crime deterrent. How employees are rewarded, and how workers are recruited and dismissed can either prevent or encourage theft. Rewarding honest workers mitigates farm thefts since it can increase guardianship measures. When employees are genuinely rewarded, they feel part of the family or community. Theft of farm items such as tools and small equipment and farm produce is significantly reduced if employees are properly rewarded in terms of on-time payment of dues and fair wages for the work done.

Lastly, the rural policing systems in Kenya are not effective for deterring crime. There are not enough police and police patrols in agricultural areas to have any impact in reducing farm crime. Also, there is a traditional reluctance by farmers to seek assistance from law enforcement agencies, which increases the opportunities for further farm crime victimisation as criminals know that chances of farmers calling the police or being seen and apprehended by the police during the commission of a crime are very slim (Bunei et al 2014).

\section{Observations, Discussion and Conclusions}

The objective of this article was to build upon the existing criminological literature by completing the first examination of farm crime victimisation in Kenya utilising Routine Activity Theory. Specifically, this research aimed to explain why certain farms, farmers and farm property are frequent targets of criminals. The article widens the research on rural criminology and supports the authors' view that Routine Activity Theory has significant potential as an appropriate conceptual framework to facilitate a better understanding of the nature and extent of farm crimes and to develop appropriate solutions to the problem. Indeed, there is a strong link between the size and volume of farm property, the location of farm property, the characteristics of farmers and farm families, the attractiveness of targets on a farm, capable guardianship and the frequency of farm thefts in Kenya. This indicates a convergence of elements specified within Routine Activity Theory that helps us understand why motivated criminals increasingly see agricultural operations as opportunistic localities for theft. 
While the study did not dwell much on what predisposes criminals to steal farm property, nevertheless the main reason which drives criminals to steal farm property is the urge for money that can be spent on food, alcohol, and cell phones and other things that represent a modern, urban style of living. Coupled with criminal opportunities which present themselves on farms in terms of suitable farm property and general absence of effective guardianship, farm crime is becoming more problematic in Kenya. One of the major contributions of this study is that some farming activities such as pay days, direct selling to nearby communities, fixed or unchanging farming routines and lack of farmer security consciousness are increasing the likelihood of agricultural victimisation in Kenya.

The paper also contributes to a growing body of knowledge about farm crime victimisation as it demonstrates that frequently victimised farmers exhibit certain social characteristics. In this study, two major characteristics of farmers (gender and age) were predictive of victimisation of cattle theft and general farm fraud and con. Indeed, rural agricultural extension officers, relatives, employees and business people are more likely to attempt to con or deceive aging farmers of their income in terms of fake farm inputs and consultancy. On the other hand, cattle thieves strike at night aiming for households that are headed by females or those who are widowed.

In addition to the above, farms that are large, adjacent to residential developments, on less trafficked roads as well located off road and public highways are more likely to be visited by thieves. For example, green maize is mostly stolen in accordance with this pattern, which mirrors findings by Barclay in Australia (2001). She linked increased victimisation on farms to improvement in road networks coupled with encroachment of urbanisation on rural areas. These changes have increased the visibility, attractiveness and accessibility to farm properties in many parts of rural Australia. Farm produce that is in high demand, easily sold, has a ready market, and can be readily cooked or used in the kitchen are major targets for thievery. Thieves tend to steal toward evening from 17:00hrs (5 PM), overnight, and early morning up to 03:00hrs (3 AM) in Kenya, and during and immediately after it has rained. Guards in rural areas are nearly nonexistent and unaffordable to all but a few wealthy farmers, and even when guards are use, they are not effective due to greater difficulty in monitoring farmlands which are often both remote and large.

The study has also demonstrated that the changing dynamics of social, cultural and economic characteristics of rural areas in terms of unemployment (especially among youth), poverty and drug use and abuse is associated with the theft of farm property. Indeed, the pressure to survive and to provide for other family members is pushing many Kenyans to turn to the highly lucrative sector of agriculture to steal green "gold" in terms of livestock, grain, farm implements and so on. The need and/or lack of money is what motivates criminals to take advantage of relaxed attitudes in farming communities, the predictable routines of farmers, and 
the general absence of capable guardianship. As cost of basic needs and farm inputs and prices of farm products increases, thefts of farm property also increases because they become more attractive targets.

We have also observed that the decline of societal values has greatly reduced informal social controls that were once the only source of guardianship in the smaller, rural villages of traditional African society. For instance, a majority of youths yearn for expensive, urban-based lifestyles, that has encouraged them to migrate to cities in search of jobs, leisure, and other trappings of modern life. The consequence is decreased guardianship in rural areas (Maguire et al 2007). Also, the effect of globalisation is that it has influenced younger people to admire western culture, leisure, fashion and entertainment, that is, a lifestyle they cannot always afford. This pushes younger people to steal farm property so as to access these activities and properties.

Another observation is that work habits in the form of an increased number of household members who travel outside the vicinity of farmsteads have decreased guardianship. For example, as mothers seek to add a shilling or two to the family budget through full or part-time non-farm jobs, and children go to school for lengthier times due proliferation of private schools. When they grow up, they leave for the city. In the long-term, any kind of population decrease in rural communities has the potential to decrease guardianship. Altogether, these changes have decreased the natural guardianship of farm property in Kenya.

Coupled with all of the factors already cited, improved transportation systems filled with motorbikes makes identity of a thief more difficult. In turn, this encourages offenders who use these bikes for easy escape without being identified. Hence, the proliferation of motorbikes in the rural areas of Kenya and who shuttle between rural and urban areas have increased opportunities for predatory criminals to evade apprehension.

In conclusion, the changing social-economic conditions of Kenya are themselves generators of farm crime by decreasing traditional or informal controls in rural Kenya and increasing the number of potential thieves who see farm operations as a source of food and money. As a result, disgruntled and jobless youths, dissatisfied employees, relatives and children, alcoholic employees and neighbours, unprofessional extension workers and dishonest and profit "hungry" business people are finding it easy and attractive to steal or support stealing of valuable and visible farm products from farmers who themselves are not always able to offer effective protection to their property. 


\section{Endnotes}

${ }^{1}$ The game is played by depositing and arranging the pebbles in the holes, partly according to rules and partly according to personal style. There were six rounds in the game, or as many as would enable one player to win six times.

${ }^{2} \mathrm{~A}$ traditional brew made in Kenya through fermentation of ground maize.

${ }^{3}$ It is a Kiswahili word meaning border to border. It is used in Kenya to refer to motorcycles' ability to reach one point to another.

${ }^{4}$ Peel bananas which have been cooked. It is common meal in Kenya which originated from Uganda.

\section{References}

African Agricultural Review (2012). The changing face of agriculture. Published October. Available online: http://www.capital.nedbank.co.za/nedbank/action/media/downloadFile?media_fileid=80 9 (Accessed on 11 November 2015)

All Africa (2010) Kenya: Theft spoils party for local coffee producers. Available online at http://allafrica.com/stories/201105110135.html. Retrieved on October 20, 2015.

Anderson, D. (1986), Stock theft and moral economy in Kenya, African Journal of International African Institute, 56 (4): 399-415, https://doi.org/10.2307/1159997

Barclay, E. M. (2001). A Review of Related Literature on Agricultural crime. Institute for Rural Futures, University of New England. Available online at www.criminologyresearchcouncil.gov.au/reports/barclay.pdf. Retrieved on $21^{\text {st }}$ November, 2010

Bunei, E. (2014). Factors influencing agricultural crimes in Kenya. MA Dissertation. Eldoret, Kenya: Moi University.

Bunei, E.K., Auya, S. and Rono J.K. (2016). Agricultural crimes in Africa: Trends and perspectives, in Donnermeyer, J.F. (Ed.), The Routledge International Handbook of Rural Criminology pp 117-126). London, Routledge. 
Bunei E.K., Rono J.K. and Chessa S.R. (2014) Crime prevention on farms: The opinion of farmers. International Journal of Rural Criminology 2(2): 209-224. Available online at http://hdl.handle.net/1811/61594. (Accessed on 11 October 2014).

Bunei E, Rono J and Chessa S (2013) Factors influencing farm crimes in Kenya: Opinions and experiences from farmers. International Journal of Rural Criminology 2(1): 75-100. Online. Available online at: http://hdl.handle.net/1811/58846 (accessed on 11 October 2014).

Burke, R. H. (2009) An introduction to criminological theory. London: Willan.

Bursik, R. J., and Grasmick. H. G (1993). Neighbourhoods and crime: The dimensions of effective community control. New York: Lexington Books.

Business Daily (2011). Coffee theft cartels harvest from new price boom. Daily Nation Media, Nairobi. Published on $5^{\text {th }}$ January 2011. Retrieved 03/11/2015 fromhttp://www.businessdailyafrica.com/Corporate-News/Coffee-theft-cartels-harvestfrom-new-price-boom/-/539550/1083612/-/blkbok/-/index.html.

CARE International in Kenya (2010). Sustainable livelihood security for the vulnerable households in Nyanza province (Dak Achana) programme. Nairobi, Kenya: CARE International in Kenya.

Cheserek G.J, Omondi P, and Odenyo V.A.O., (2012). Nature and causes of cattle rustling among some pastoral communities in Kenya. Journal of Emerging Trends in Economics and Management Sciences (JETEMS) 3(2): 173-179.

Cohen, L. E and Felson, M. (1979). Social change and crime rate trends: A routine activities approach. American Sociological Review, Vol. 44: 588-608, https://doi.org/10.2307/2094589

Daily Nation (2013). Poor youths team up with butchers to drive spate of cattle theft in Kisumu. Daily Nation Media, Nairobi. Published on $30^{\text {th }}$ November 2015. Retrieved 03/11/2015 from http://www.nation.co.ke/news/Poor-youths-team-up-with-butchers-todrive-spate-of-cattle-theft/1056-2093670-format-xhtml-3ch3mfz/index.html.

Felson, M. (1998). Crime \& everyday life. Thousand Oaks, California: Pine Forge Press.

Foeken, D., Owuor, S. O. and Waver, W. (2002). Crop cultivation in NakurutTown, Kenya: Practice and Potential. ASC Working Paper 50/2002, African Studies Centre, Netherlands 
Foeken, D. and Mwangi, A. M. (2000). Increasing food security through urban farming in Nairobi. In N. Bakker, M. Dubbeling, S. Guendel, U. Sabel-Koschella and H. de Zeeuw (Eds.), Growing cities, growing food - urban agriculture on the policy agenda (pp. 303327). Eurasburg, Germany: German Foundation for International Development (DSE, Deutsche Stiftung für Internationale Entwicklung).

Francis P., and Amuyunzu-Nyamongo M. (2007). Bitter harvest: The social costs of state failure in rural Kenya. In Moser C and Dani A. (Eds.), Community Based Institutions and Asset Creation (pp 303-327). Washington, DC: World Bank.

German, L., Masuku, Y., Odenya, J. and Geta, E. (2006) Beyond the Farm: A new look at livelihoods constraints in the Eastern African Highlands. African Highlands Initiative, Working Papers \#12. Kampala, Uganda: African Highlands Initiative.

Gichamo, T. Z. (2011) Dispute or residing together in harmony? Bean cultivation and theft in rural Ethiopia. MA thesis. Lund, Sweden: Swedish University of Agricultural Sciences.

Gitu, S. (2012) Kahawa Yetu - “Our Coffee.” A need for better organizational capacity in Kenya's Coffee's Cooperatives, A case study of new Gatanga Coffee Cooperative Society, Kenya. Unpublished Master Thesis. Guelph, Canada: University of Guelph.

Indakwa, E (2013). Rampant petty theft and alcoholism rooted in our failed agriculture sector, in The Standard Newspaper, Standard Group: Nairobi: 38. Publish on $8^{\text {th }}$ September, 2013. https://www.standardmedia.co.ke/article/2000093034/rampant-petty-theft-andalcoholism-rooted-in-our-failed-agriculture-sector

Jones J. (2010). Farm crime on Anglesey: Local partner's and organisations' views on the issue. Retrieved on $7^{\text {th }}$ December, 2011. Second report, January. Available online at http://www.aber.ac.uk/en/media/jane-jones---second-report.pdf.

Juma M., Nyangena, W., and Yesuf, M. (2009). Production risk and farm technology in rainfed semi-arid lands of Kenya. Nairobi, Kenya: Environment for Development Kenya.

Kilalo, D., Olubayo, F., Obukosia, S., and Shibairo, S.I. (2009). Farmer management practices of citrus insect pests in Kenya. African Journal of Horticultural Science, 2:168-176.

Makiche, E (2013), Agony of farmers losing millions of shillings to bloody livestock merchants. The Business Beat Magazine, Standard Group: Nairobi: 3. Publish on $2^{\text {nd }}$ July, 2013. https://www.standardmedia.co.ke/business/article/2000087275/agony-of-farmers-losingmillions-of-shillings-to-bloody-livestock-merchants 
Mawusi, S.E. (2004), Farmers' knowledge and perception towards a sustainable adoption of sugar beet in Kenya. MA Dissertation. Lund University, Sweden.

Mears, D.P., Scott, M.L. and Bhati, A.S. (2007), Opportunity theory and agricultural crime victimization. Rural Sociology, 72, 151-184, https://doi.org/10.1526/003601107781170044

Mutua, J. (2004) Some Challenges to the use of donkeys in Kenya. In Starkey, P. and Kaumbutho P. (eds), Donkeys, People and Development: A Resource Book of the Animal Traction Network for Eastern and Southern Africa 9 (pp 99-101). Wageningen, Netherlands: ACP - EU Technical Centre for Agricultural and Rural Cooperation (CTA).

Omiti, J. (2006), Participatory prioritization of issues in smallholder agricultural commercialization in Kenya. Nairobi, Kenya: KIPPRA Annual Report 2006/07.

Ochieng, J. Owuor, G. and Bebe B. O. (2013) "Management practices and challenges in smallholder indigenous chicken production in Western Kenya," Journal of Agriculture and Rural Development in the Tropics and Subtropics, 114 (1), 51-58.

Osamba, J.O (2000): The Sociology of insecurity: Cattle rustling and banditry in North-Western Kenya. African Journal on Conflict Resolution, 1(2), 11-37.

Osborn, E. (2015), Examining macro-level correlates of farm equipment theft: A test of routine Activity theory and social disorganization theory. Ph.D. Dissertation. Louisville, Kentucky: University of Louisville. Available online at http://ir.library.louisville.edu/etd/2248?utm_source=ir.library.louisville.edu\%2Fetd\%2F2 248\&utm_medium=PDF\&utm_campaign=PDFCoverPages (retrieved on $16^{\text {th }}$ October, 2015)

Republic of Kenya. (2010a). Kenya population and census, 2009. Nairobi, Kenya: Government Printer.

Republic of Kenya. (2010b). Kenya Criminal Appeal No.7 of 2010. Nairobi, Kenya: Kenya Law Reforms.

Sevelius, B. Y. (2012). The characteristics of the poor people in rural Kenya. A case study of Kisii central district. MA Dissertation, Kenyatta University, Nairobi, Kenya. Available online at http://ir-library.ku.ac.ke/handle/123456789/4059 
Standard Newspaper. (2011). Rampant coffee theft worries. Standard Group, Nairobi. Published on $29^{\text {th }}$ November 2011. Retrieved 03/11/2015

from http://www.standardmedia.co.ke/business/article/2000047480/rampant-coffee-theftworries-farmers.

Standard Newspaper (2014a). Taveta farmers now write their names on bananas as protection against thieves. Standard Group: Nairobi: Retrieved 11/11/2015 from http://www.standardmedia.co.ke/mobile/article/2000101865/thieves-leave-farmerswith-no-option-but-to-brand-bananas. Published on $9^{\text {th }}$ January, 2014.

Standard Newspaper. (2014b). Houses redesigned to keep livestock safe in Kuria in The Life Magazine, pp 9. Standard Group, Nairobi, 17. Published on $9^{\text {th }}$ May 2014. Retrieved 11/10/2015 from https://www.standardmedia.co.ke/article/2000122660/housesredesigned-to-keep-livestock-safe-in-kuria

Standard Newspaper. (2014c). Fake lecturer who conned farmers still on the run a year later. Standard Group, Nairobi, 17. Published on $11^{\text {th }}$ January, 2014. Retrieved 1/09/2015 from https://www.standardmedia.co.ke/article/2000102020/fake-lecturer-who-conned-farmersstill-on-the-run-a-year-later.

Standard Newspaper (2015a). Police in Baringo intercept suspected stolen livestock Sunday night. Standard Group: Nairobi. Published on $20^{\text {th }}$ January, 2015. Retrieved 12/11/2015 from https://www.standardmedia.co.ke/article/2000169837/police-in-baringo-interceptsuspected-stolen-livestock-sunday-night.

Standard Newspaper (2015b). Suspects nabbed with donkey meat link cartel to Burma market. Published on $28^{\text {th }}$ February, 2015. Retrieved 11/11/2015 from http://www.standardmedia.co.ke/health/article/2000153161/suspects-nabbed-withdonkey-meat-link-cartel-to-burma-market.

Stavrou, A. (2002). Crime in Nairobi: Results of a citywide victim survey. Nairobi, Kenya: UnHabitat.

Titonell, P., Shepherd, K.D., Vanlanwe B. and Giller, K.E. (2007) Nature and causes of cattle rustling among some pastoral communities in Kenya. Journal of Emerging Trends in Economics and Management Sciences (JETEMS) 3(2), 173-179.

Verma, R. (2001). From gender, land and livelihoods in East Africa: through farmers' eyes. Pub. IDRC. Available online at http://www.idrc.ca/EN/Resources/Publications/Pages/IDRCBookDetails.aspx?Publicatio nID=249 (accessed on 28 November 2014). 